\title{
Hydrochemistry and geothermometry of an Albian aquifer from Oued Righ region in northeastern Algerian Sahara
}

\author{
Warda Chaib* and Nacer Kherici
}

\author{
* Correspondence: hydro_ha@ \\ yahoo.fr \\ Hydrogeology Department, Faculty \\ of Earth Sciences, Badji Mokhtar \\ University, Annaba 23000, Algeria
}

\begin{abstract}
Background: The area of Oued Righ is one of the important geothermal areas in northeastern Algerian Sahara. It is characterized by a hot arid climate with intense dryness and very high evaporation rates. The water requirements of the Oued Righ region are provided by groundwater resources contained in the two aquifers: the complex terminal and the deeper confined continental intercalaire aquifer.

Methods: Twenty-seven samples were taken in November 2010 and April 2012; Water samples were analyzed for major and minor dissolved chemical constituents.

Results: Samples collected from the $\mathrm{Cl}$ aquifer are characterized by high temperatures varying from $40^{\circ} \mathrm{C}$ to $60^{\circ} \mathrm{C}$ and conductivities of 2110 to $3370 \mu \mathrm{S} /$ $\mathrm{cm}$. The total dissolved solids (TDS) of the thermal waters range from 1488 to $5480 \mathrm{mg} / \mathrm{l}$. The waters are generally of sodium and magnesium sulfated and sodium chlorinated types. The results of mineral equilibrium modeling indicate that the thermal waters of Oued Righ are undersaturated with respect to evaporite minerals and oversaturated or nearly in equilibrium with respect to dolomite, calcite, and aragonite. This paper presents ternary diagrams of $\mathrm{Na}-\mathrm{K}-\mathrm{Mg}^{1 / 2}$ and $\mathrm{Cl}-\mathrm{SO}_{4}-\mathrm{HCO}_{3}$ and a calculation model, which allows location of geothermal water with the two diagrams, involving knowledge of their chemical composition.
\end{abstract}

Conclusions: Groundwater in the Albian aquifer of Oued Righ shows a change in its chemical properties between the two sampling periods, resulting from water-rock interactions and mixing processes.

Keywords: Continental intercalaire; Thermal waters; Oued Righ; Minerals

\section{Background}

The groundwater reservoir of the continental intercalaire $(\mathrm{CI})$ is the deep reservoir of the septentrional Sahara. The continental intercalaire aquifer of North Africa is one of the largest confined aquifers in the world, comparable in scale to the great artesian basin of Australia and covers some $600,000 \mathrm{~km}^{2}$ on only Algerian and Tunisian territories with a potential reservoir thickness of between 120 and $1000 \mathrm{~m}$ (Castany 1982). 
The water chemistry is of $\mathrm{Na}-\mathrm{SO}_{4}-\mathrm{Cl}$ composition, and the total dissolved solids (TDS) of the thermal waters range from 1488 to $5480 \mathrm{mg} / \mathrm{l}$. Its temperatures range from $40^{\circ} \mathrm{C}$ to $60^{\circ} \mathrm{C}$. The current studies in the area are directed towards the geochemical evaluation of thermal waters in the Oued Righ field on the basis of chemical geothermometry and mineral equilibrium calculations.

\section{Study area}

The area is located in the northeastern Algerian Sahara. It is limited by large chotts and the piedmonts of Zab to the north, by the Mio-Pliocene and Turonien plateaus of the dorsal Mozabite and Daias plateaus to the west, by the sandy regs of the Ouarglie area to the south, and by the dune belt of the Grand Erg Oriental to the east. The study area is considered to be arid, the mean annual precipitation is less than $100 \mathrm{~mm}$, and the mean annual temperature is around $22^{\circ} \mathrm{C}$. The mean annual potential evapotranspiration is approximately $1165 \mathrm{~mm}$.

\section{Geology and hydrogeology}

In the study area, there are two aquifer systems, separated by thick argillaceous and evaporitic series, base of the upper Cretaceous: the CI and complex terminal (CT) (Figure 1). The geology of the studied area has been investigated by several authors (Cornet 1964; Bishop 1975; Castany 1982). The CI aquifer is located within a complex succession of clastic

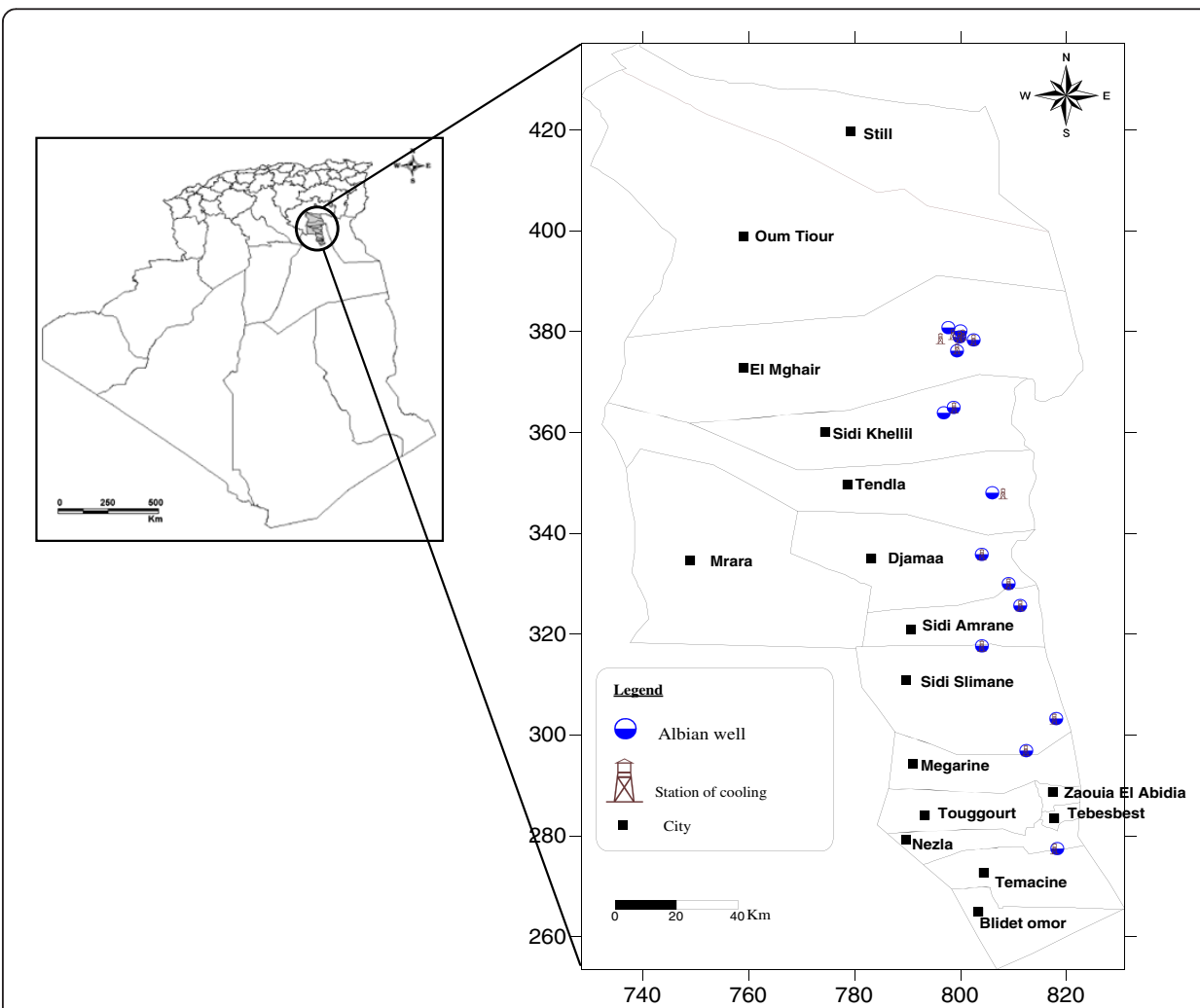

Figure 1 Location map of the studied area (Oued Righ). 


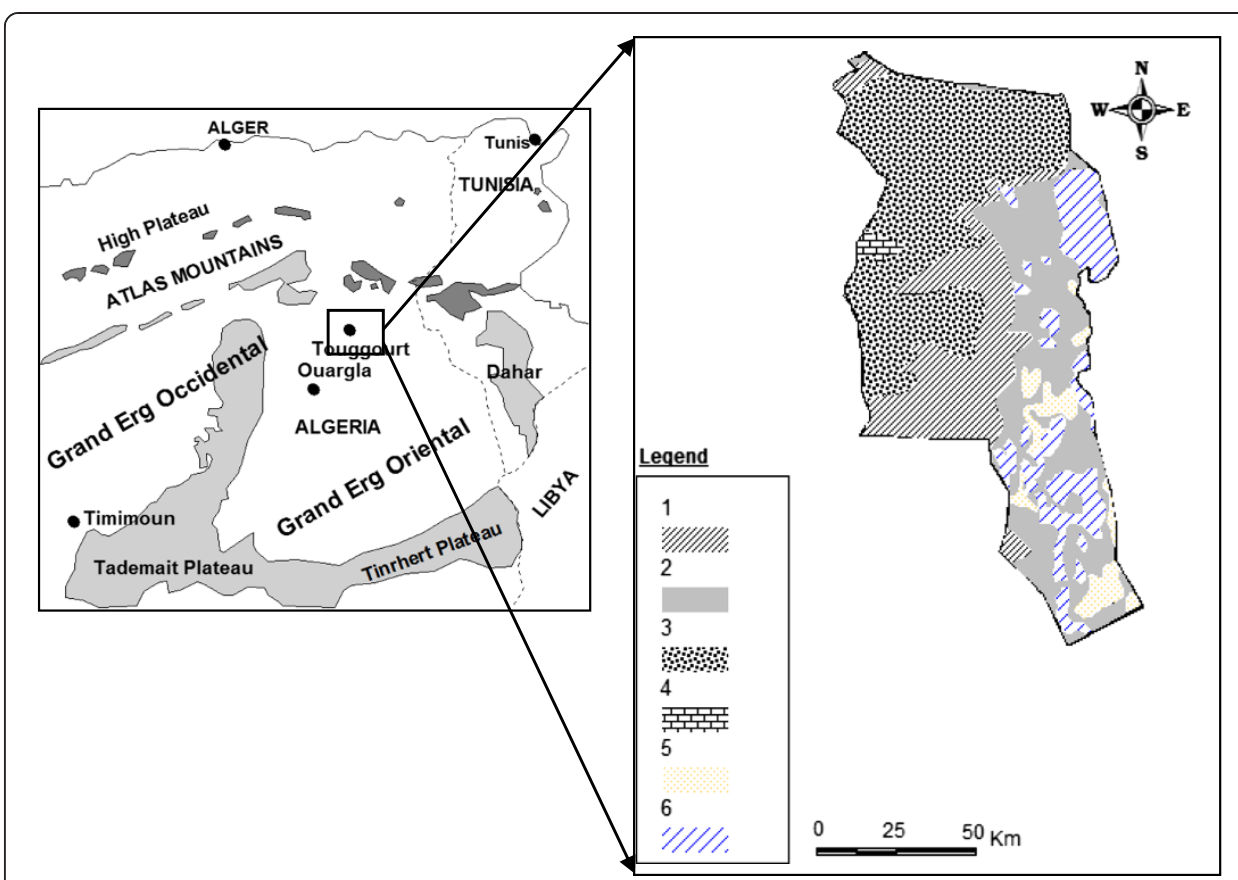

Figure 2 Geological map of the study area. This map is extracted from the geologic map of the Mesozoic basin of the Sahara Algero-Tunisian (Busson 1967). 1 Miocene or Pliocene (with locally continental nummulitic), 2 Quaternary, 3 Pliocene or former Quaternary, 4 upper middle Eocene, 5 dunes, 6 chotts.

sediments of Mesozoic age; the thickness and lithology of which show significant lateral variation (UNESCO 1972) (Figure 2).

The aquifer is, however, hydraulically continuous over the whole basin from north to south from the Saharan Atlas to the Tinrhet Plateau and further south to the Tassili Mountains of the Hoggar, and west to east from western Algeria to the Libyan border (Edmunds et al. 2003).

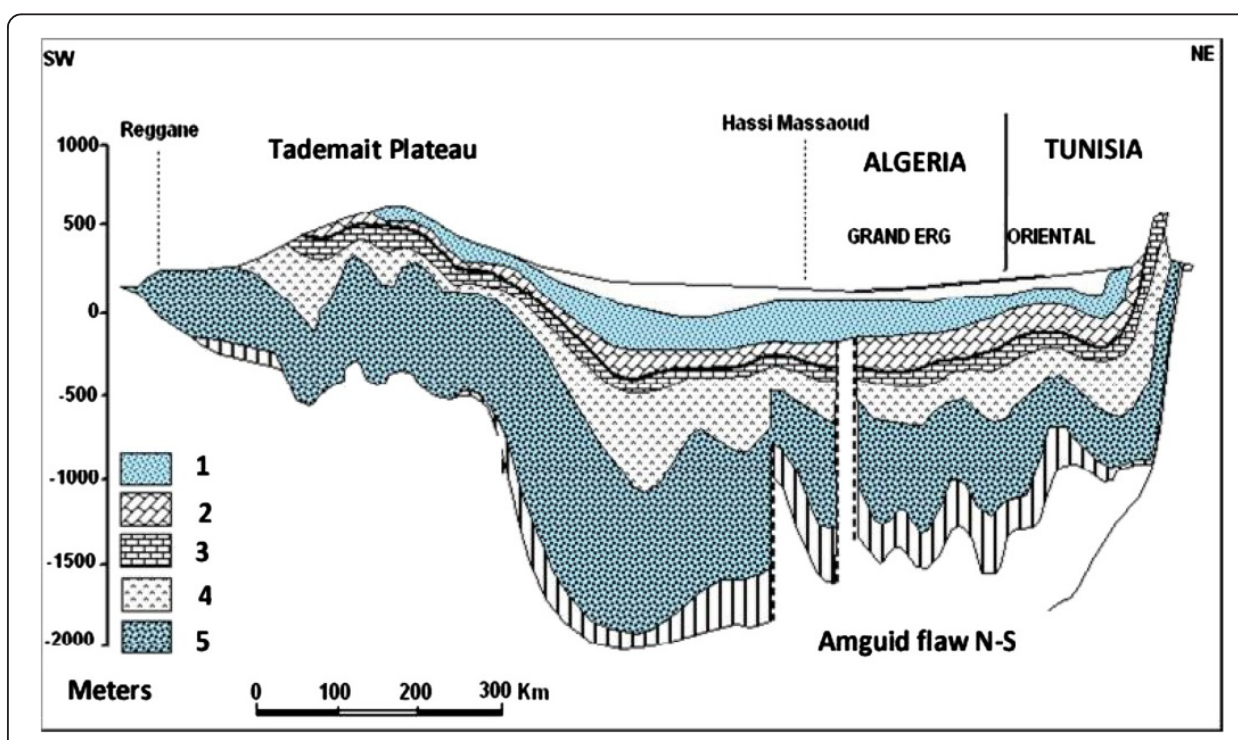

Figure 3 Synthetic hydrogeological section across the septentrional Sahara (UNESCO 1972). 1 Continental terminal aquifer, 2 Lower Senonian, 3 Turonian evaporates, 4 Cenomanian, 5 continental intercalaire aquifer. 


\section{Methods}

Twenty-seven samples were taken in November 2010 and April 2012; the geographical location of the sampling site is shown in Figure 3. The physicochemical parameters (temperature, $\mathrm{pH}$, and electric conductivity) were measured in situ using a WTW multiparameter (Weilheim, Germany). Water samples were analyzed for major and minor dissolved chemical constituents. $\mathrm{Ca}, \mathrm{Mg}, \mathrm{Cl}$, and $\mathrm{HCO}_{3}$ were determined by the titration method. $\mathrm{SO}_{4}$ was determined using spectrophotometric method. $\mathrm{Na}$ and $\mathrm{K}$ were analyzed using a flame photometer. Mineral saturation indices for a number of common minerals potentially present in the studied localities were calculated at measured discharge temperatures using PHREEQC 2.7 (US Geological Survey, Denver, Colorado) (Parkhurst and Appelo 1999) interfaced with Diagrams 5.8.

\section{Results and discussion}

\section{Hydrogeochemical properties of thermal waters}

Samples collected from the $\mathrm{CI}$ aquifer are characterized by high temperatures varying from $47.5^{\circ} \mathrm{C}$ to $60.4^{\circ} \mathrm{C}$ in November 2010 and $40.5^{\circ} \mathrm{C}$ to $61.3^{\circ} \mathrm{C}$ in April 2012 (Table 1). The conductivity values in the CI groundwater range from 2130 to $3300 \mu \mathrm{S} / \mathrm{cm}$ (November 2010) and 2110 to $3370 \mu \mathrm{S} / \mathrm{cm}$ (April 2012), having average TDS values of 1488 to $5480 \mathrm{mg} / \mathrm{l}$ (April 2012) and 1563 to $2047 \mathrm{mg} / \mathrm{l}$ (November 2010).

Dominant cations are mainly sodium and calcium and range, respectively, from 211.26 to $370.20 \mathrm{mg} / \mathrm{l}$ and from 108 to $208 \mathrm{mg} / \mathrm{l}$ (November 2010) (Table 2). The second period (April 2012) of the CI aquifer has sodium ranging from 117.5 to $298.75 \mathrm{mg} / \mathrm{l}$ and calcium varying between 132 and $216.8 \mathrm{mg} / \mathrm{l}$ (Table 3). Dominant anions are sulfate (266.18 to $4450.91 \mathrm{mg} / \mathrm{l}$ ) and chloride (305.30 to $683.37 \mathrm{mg} / \mathrm{l}$ ) in April 2012. The water samples for the period November 2012 are characterized by sulfate ( 410.10 to $714.54 \mathrm{mg} / \mathrm{l}$ ) and chloride (312.40 to $695.80 \mathrm{mg} / \mathrm{l})$. Variable water types may indicate different hydrogeochemical processes such

Table 1 Variation of temperature in Albian wells (April 2012 and November 2010)

\begin{tabular}{|c|c|c|c|}
\hline \multicolumn{2}{|l|}{ April 2012} & \multicolumn{2}{|c|}{ November 2010} \\
\hline Well name & Temperature $\left({ }^{\circ} \mathrm{C}\right)$ & Well name & Temperature $\left({ }^{\circ} \mathrm{C}\right)$ \\
\hline Cl1ST22 & 53.2 & Cl1ST22 & 48.4 \\
\hline Cl1ST10 & 50.3 & Cl1ST19 & 54.7 \\
\hline $\mathrm{Cl} 2 \mathrm{SM} 4$ & 49.5 & Cl1ST10 & 56.4 \\
\hline Cl1SM5 & 49.2 & Cl1SD14 & 54.4 \\
\hline Cl1SM3 & 55.5 & CI3SD10 & 52 \\
\hline SD14 & 50 & SD1 & 50.8 \\
\hline SD7 & 46.2 & Cl1SD5 & 53 \\
\hline $\mathrm{SD} 1$ & 49 & Cl1SD7 & 53.1 \\
\hline Cl1SM1 & 41 & $\mathrm{Cl} 2 \mathrm{SM} 3$ & 47.5 \\
\hline SD5 & 40.5 & CI3SM3 & 58 \\
\hline SD10 & 52.7 & Cl1SM5 & 56.4 \\
\hline Cl1SM4 & 59.9 & Cl1SM3 & 60.4 \\
\hline $\mathrm{Cl} 2 \mathrm{SM} 3$ & 49 & Cl1SM1 & 50 \\
\hline Cl3SM3 & 61.3 & & \\
\hline
\end{tabular}


Table 2 Chemical data for the Albian aquifer from the study area (November 2010)

\begin{tabular}{|c|c|c|c|c|c|c|c|c|c|c|c|c|}
\hline Sample ID & $\mathrm{pH}$ & $\begin{array}{c}\text { C.E. } \\
(\mu \mathrm{S} / \mathrm{cm})\end{array}$ & $\begin{array}{c}\text { Salinity } \\
(\mathbf{g} / \mathrm{l})\end{array}$ & $\begin{array}{c}\mathrm{Ca} \\
(\mathrm{mg} / \mathrm{l})\end{array}$ & $\begin{array}{c}\mathrm{Mg} \\
(\mathrm{mg} / \mathrm{l})\end{array}$ & $\begin{array}{c}\mathrm{Na} \\
(\mathrm{mg} / \mathrm{l})\end{array}$ & $\begin{array}{c}\mathrm{K} \\
(\mathrm{mg} / \mathrm{l}) \\
\end{array}$ & $\begin{array}{c}\mathrm{Cl} \\
(\mathrm{mg} / \mathrm{l})\end{array}$ & $\begin{array}{c}\mathrm{SO}_{4} \\
(\mathrm{mg} / \mathrm{l})\end{array}$ & $\begin{array}{l}\mathrm{HCO}_{3} \\
(\mathrm{mg} / \mathrm{l})\end{array}$ & $\begin{array}{c}\mathrm{CO}_{3} \\
(\mathrm{mg} / \mathrm{l})\end{array}$ & $\begin{array}{c}\text { TDS } \\
(\mathrm{mg} / \mathrm{l})\end{array}$ \\
\hline CI1ST22 & 8.78 & 2720 & 1.4 & 154.4 & 84.96 & 370.20 & 51.60 & 518.30 & 679.41 & 178.12 & 4.8 & 2042 \\
\hline Cl1ST19 & 8.7 & 2780 & 1.6 & 160 & 76.8 & 270.86 & 49.95 & 525.40 & 636.47 & 185.44 & 0 & 1905 \\
\hline Cl1ST10 & 8.66 & 3300 & 1.8 & 153.6 & 115.20 & 316.56 & 48.85 & 695.80 & 558.41 & 158.6 & 0 & 2047 \\
\hline CI1SD14 & 8.33 & 2450 & 1.3 & 165.6 & 70.08 & 257.62 & 49.40 & 411.80 & 714.54 & 178.12 & 2.4 & 1850 \\
\hline CI3SD10 & 8.16 & 2460 & 1.3 & 161.6 & 66.24 & 317.22 & 48.85 & 426.00 & 433.41 & 187.88 & 3.6 & 1645 \\
\hline SD1 & 7.52 & 2500 & 1.3 & 116 & 73.92 & 330.46 & 47.75 & 454.40 & 441.32 & 224.48 & 0 & 1688 \\
\hline Cl1SD5 & 8.81 & 2440 & 1.3 & 208 & 17.28 & 303.97 & 49.95 & 440.20 & 410.10 & 190.32 & 3.6 & 1624 \\
\hline Cl1SD7 & 8.91 & 2470 & 1.3 & 162.4 & 61.44 & 211.26 & 49.40 & 411.80 & 655.99 & 192.76 & 0 & 1745 \\
\hline $\mathrm{Cl} 2 \mathrm{SM} 3$ & 8.97 & 2470 & 1.3 & 182.4 & 94.08 & 297.35 & 51.60 & 390.50 & 613.06 & 146.4 & 14.4 & 1790 \\
\hline Cl3SM3 & 9.1 & 2260 & 1.2 & 108 & 124.80 & 277.48 & 47.75 & 319.50 & 546.70 & 161.04 & 2.4 & 1588 \\
\hline Cl1SM5 & 8.7 & 2130 & 1.1 & 132 & 91.20 & 257.62 & 48.85 & 312.40 & 655.99 & 148.84 & 4.8 & 1652 \\
\hline $1 \mathrm{SM} 3$ & 8.94 & 2130 & 1.2 & 130.4 & 92.16 & 217.88 & 48.30 & 312.40 & 534.99 & 226.92 & 0 & 1563 \\
\hline Cl1SM1 & 9.33 & 2670 & 1.4 & 192 & 89.76 & 290.73 & 48.85 & 454.40 & 624.77 & 131.76 & 7.2 & 1840 \\
\hline
\end{tabular}

C.E: electric conductivity

as mixing and water-rock interaction (El-Fiky 2008). A piper trilinear diagram (Figure 4) shows that all the thermal waters are characterized by the dominance of $\mathrm{Cl}+\mathrm{SO}_{4}$ over $\mathrm{HCO}_{3}$ and $\mathrm{Na}+\mathrm{K}$ over $\mathrm{Ca}+\mathrm{Mg}$ for the period November 2010 and $\mathrm{SO}_{4}+\mathrm{Cl}$ over $\mathrm{HCO}_{3}$ and $\mathrm{Ca}+(\mathrm{Na}+\mathrm{K})$ over $\mathrm{Mg}$ for the period April 2012. The sodium sulfated type is present in 53.85\% of the samples for the period November 2010 and 7.14\% for the period April 2012; some samples are rich in chloride and sodium, showing sodium chlorinated type which represents $46.15 \%$ (November 2010) and 7.14\% (April 2012). The calcium sulfated type is present in $57.14 \%$ only for the period April 2012. Finally, the magnesium sulfated type

Table 3 Chemical data for the Albian aquifer from the study area (April 2012)

\begin{tabular}{lcccccccccccc}
\hline $\begin{array}{l}\text { Sample } \\
\text { ID }\end{array}$ & $\mathbf{p H}$ & $\begin{array}{c}\mathrm{C} . \mathrm{E} . \\
(\boldsymbol{\mu} \mathbf{\mathbf { c m }})\end{array}$ & $\begin{array}{c}\text { Salinity } \\
(\mathbf{g} / \mathbf{l})\end{array}$ & $\begin{array}{c}\mathrm{Ca} \\
(\mathbf{m g} / \mathbf{l})\end{array}$ & $\begin{array}{c}\mathbf{M g} \\
(\mathbf{m g} / \mathbf{l})\end{array}$ & $\begin{array}{c}\mathbf{N a} \\
(\mathbf{m g} / \mathbf{l})\end{array}$ & $\begin{array}{c}\mathbf{K} \\
(\mathbf{m g} / \mathbf{l})\end{array}$ & $\begin{array}{c}\mathrm{Cl} \\
(\mathbf{m g} / \mathbf{l})\end{array}$ & $\begin{array}{c}\mathbf{S O}_{4} \\
(\mathbf{m g} / \mathbf{l})\end{array}$ & $\begin{array}{c}\mathrm{HCO}_{3} \\
(\mathbf{m g} / \mathbf{l})\end{array}$ & $\begin{array}{c}\mathrm{CO}_{3} \\
(\mathbf{m g} / \mathbf{l})\end{array}$ & $\begin{array}{c}\mathrm{TDS} \\
(\mathbf{m g} / \mathbf{l})\end{array}$ \\
\hline CI1ST22 & 7.3 & 2640 & 1.4 & 196.8 & 111.12 & 230 & 42.39 & 528.95 & 111.12 & 56.12 & 0 & 1488 \\
CI1ST10 & 7.76 & 3370 & 1.7 & 174.8 & 96.72 & 298.75 & 41.77 & 683.375 & 96.72 & 62.2 & 1.2 & 4101 \\
CI2SM4 & 8.17 & 2150 & 1.1 & 152.8 & 121.44 & 123.75 & 39.33 & 305.3 & 121.44 & 45.1 & 2.4 & 3813 \\
CI1SM5 & 8.24 & 2160 & 1.1 & 165.2 & 102.96 & 117.5 & 39.94 & 319.5 & 102.96 & 45.72 & 1.8 & 3491 \\
CI1SM3 & 7.42 & 2320 & 1.2 & 204.8 & 112.8 & 130 & 46.67 & 344.35 & 112.8 & 48.8 & 0 & 4945 \\
SD14 & 8.05 & 2860 & 1.5 & 216.8 & 107.52 & 217.5 & 44.22 & 507.65 & 107.52 & 56.08 & 2.4 & 4762 \\
SD7 & 8.14 & 2500 & 1.3 & 168 & 118.08 & 192.5 & 43.00 & 459.725 & 118.08 & 51.8 & 3 & 4573 \\
SD1 & 7.23 & 2430 & 1.3 & 132 & 111.36 & 186.25 & 39.94 & 454.4 & 111.36 & 75.64 & 0 & 3480 \\
CI1SM1 & 8.26 & 2540 & 1.3 & 214.96 & 100.704 & 173.75 & 41.77 & 447.3 & 100.704 & 79.28 & 1.2 & 4267 \\
SD5 & 8.27 & 2460 & 1.3 & 209.6 & 89.76 & 186.25 & 43.61 & 511.2 & 89.76 & 112.2 & 2.4 & 3447 \\
SD10 & 7.36 & 2400 & 1.3 & 198.4 & 84.24 & 173.75 & 42.39 & 440.2 & 84.24 & 65.88 & 0 & 3752 \\
CI1SM4 & 7.13 & 2110 & 1.1 & 207.6 & 93.84 & 130 & 38.72 & 347.9 & 93.84 & 53.68 & 0 & 3509 \\
CI2SM3 & 8.34 & 2430 & 1.3 & 211.6 & 106.08 & 161.25 & 43.00 & 397.6 & 106.08 & 45.72 & 1.8 & 5480 \\
CI3SM3 & 7.55 & 2150 & 1.1 & 184.8 & 107.04 & 123.75 & 40.55 & 337.25 & 107.04 & 50.02 & 0 & 3651 \\
\hline
\end{tabular}

C.E: electric conductivity 


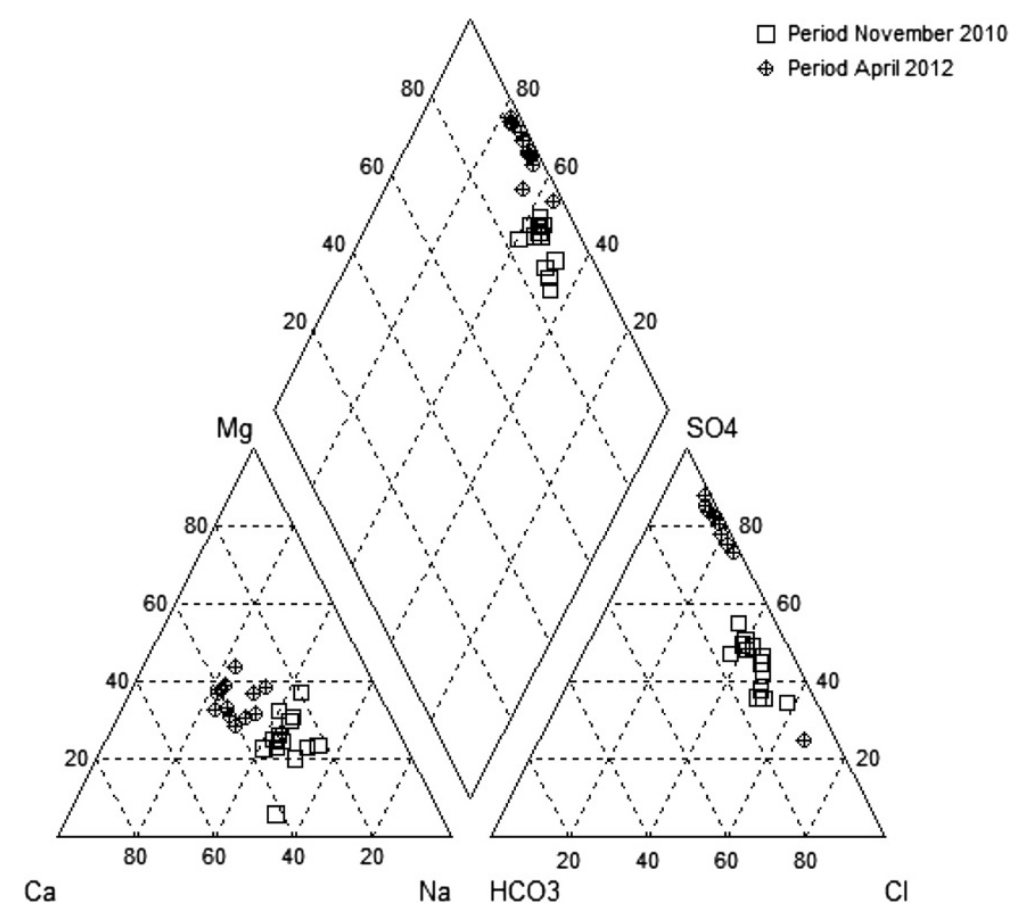

Figure 4 Distribution of the $\mathrm{Cl}$ thermal waters from the study area in Piper diagram. This is for the periods November 2010 and April 2012.

represents $28.57 \%$ for the period April 2012. This is due to the combination of mixing with cold groundwater and water-rock interaction processes in the thermal aquifers (Tarcan 2003).

\section{Mineral saturation status}

By using the saturation index approach, it is possible to predict reactive minerals in the subsurface from the groundwater chemical data without examining samples of the solid phases (Deutsch 1997).

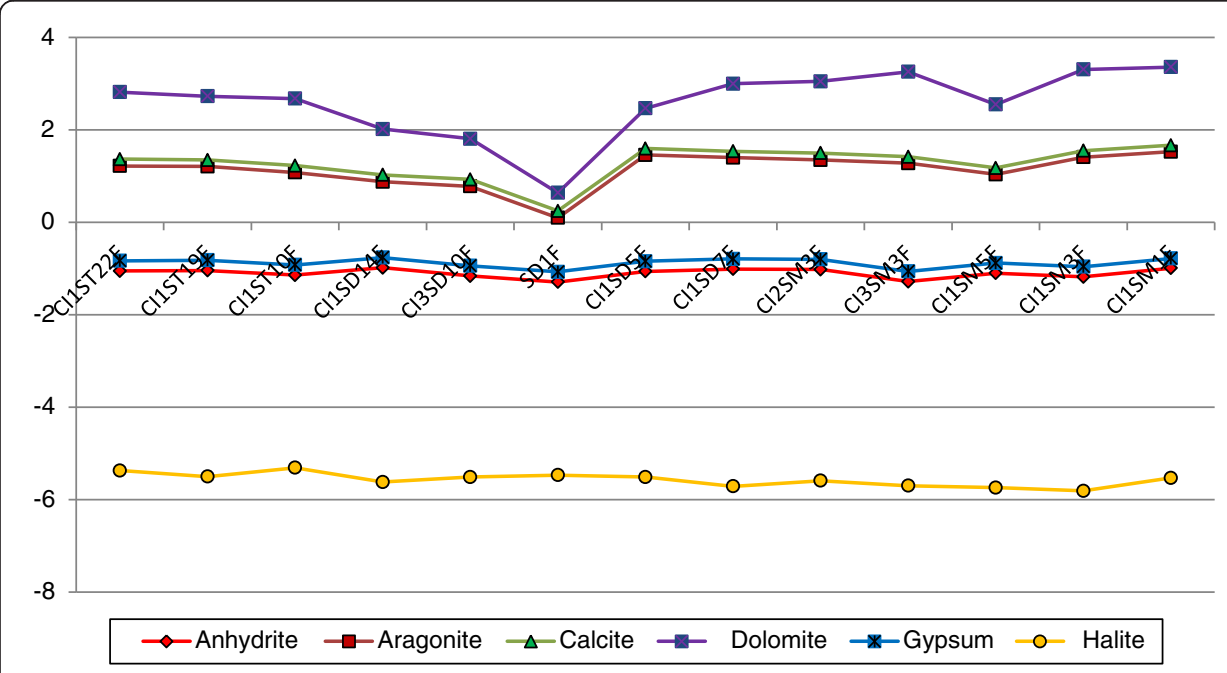

Figure 5 Saturation state of some minerals in $\mathrm{Cl}$ water from the Oued Righ area (November 2010). 
In this study, the calculation of saturation indices of carbonate (calcite, aragonite, and dolomite) and evaporite (gypsum, anhydrite, and halite) minerals with respect to the calculated water composition was performed using the PHREEQC program (Parkhurst and Appelo 1999) which uses the WATEQ Debye-Hückel equation. Values of saturation index greater than, equal to, and less than zero represent oversaturation, equilibrium, and undersaturation, respectively. All thermal waters in the study area are undersaturated with respect to evaporite minerals (gypsum, anhydrite, and halite) for the period November 2010 and for the period April 2012, indicating that these minerals are undergoing dissolution (Figures 5 and 6), and explaining the high concentration of evaporite minerals in the reservoir. We may assume that the SI values falling within the range of \pm 0.5 units from 0 indicate the equilibrium state (Pulmmer et al. 1976). Most are oversaturated or nearly in equilibrium with respect to dolomite, calcite and aragonite for the period November 2010 and for the period April 2012, indicating that these carbonate minerals occur in the groundwater.

\section{Water geochemistry}

A geothermometric technique proposed by Giggenbach (1988) discriminates between immature waters and fully equilibrated waters originating in deep reservoirs. A total of 27 completed and analyzed groundwater samples from the $\mathrm{CI}$ were used in the Giggenbach diagram (Figure 7). The $\mathrm{Na}-\mathrm{K}_{-} \mathrm{Mg}^{1 / 2}$ ternary diagram (Giggenbach 1983) is used for evaluating equilibrium between the hot waters and rocks at depth and to estimate reservoir temperature. Figure 7 shows a Na-K- $\mathrm{Mg}^{1 / 2}$ triangular diagram for thermal water samples from wells reaching the $\mathrm{CI}$ aquifer in Oued Righ data points plot adjacent to the $\mathrm{Mg}^{1 / 2}$ corner, which is typical of 'immature waters' that do not attain equilibrium with their associated rocks or mixing with superficial waters.

All the samples collected in the $\mathrm{CI}$ aquifer are plotted in the $\mathrm{Cl}_{-} \mathrm{SO}_{4}-\mathrm{HCO}_{3}$ ternary diagram (Figure 8). It is shown that the waters of Oued Righ plot between the $\mathrm{Cl}$ and $\mathrm{SO}_{4}$ fields of volcanic waters, but they never attain maturity.

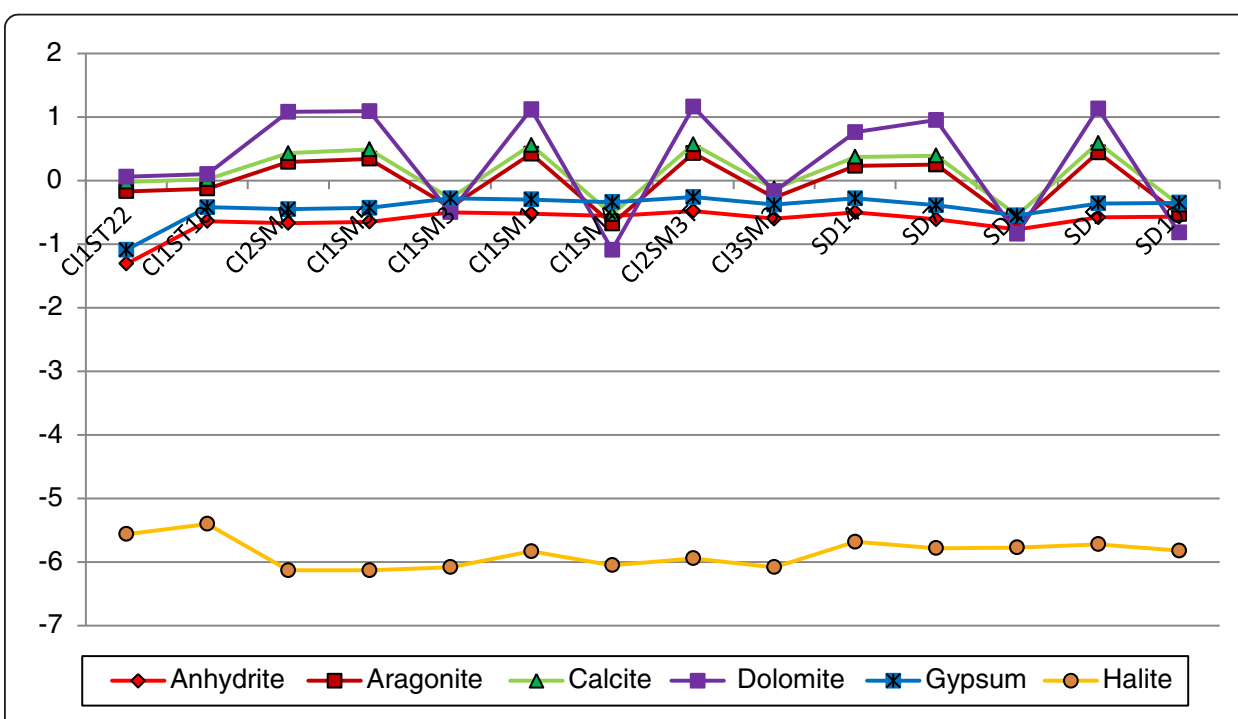

Figure 6 Saturation state of some minerals in Cl water from the Oued Righ area (April 2012). 


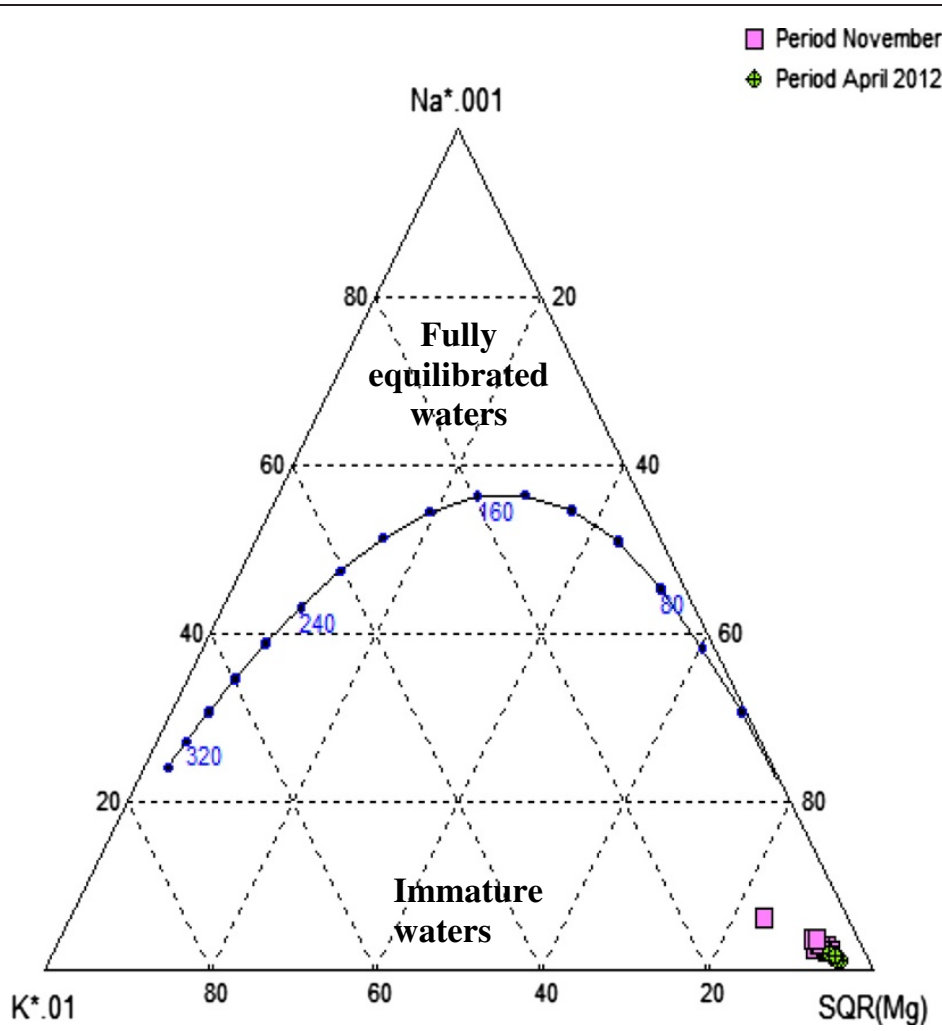

Figure 7 Distribution of the $\mathrm{Cl}$ thermal waters from the study area in the Giggenbach (1983) $\mathrm{Na}-\mathrm{K}-\mathrm{Mg}^{1 / 2}$ triangular diagram.

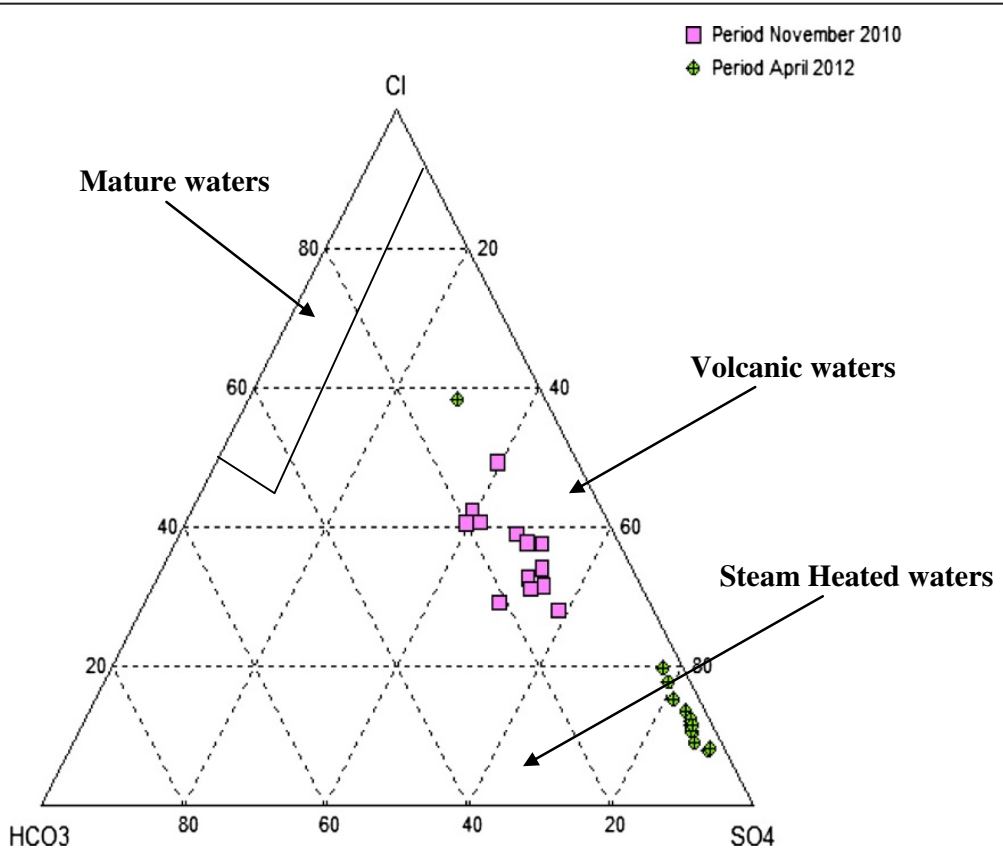

Figure 8 Distribution of the $\mathrm{Cl}$ thermal waters from the study area in the $\mathrm{Cl}-\mathrm{SO}_{4}-\mathrm{HCO}_{3}$ triangular diagram. 


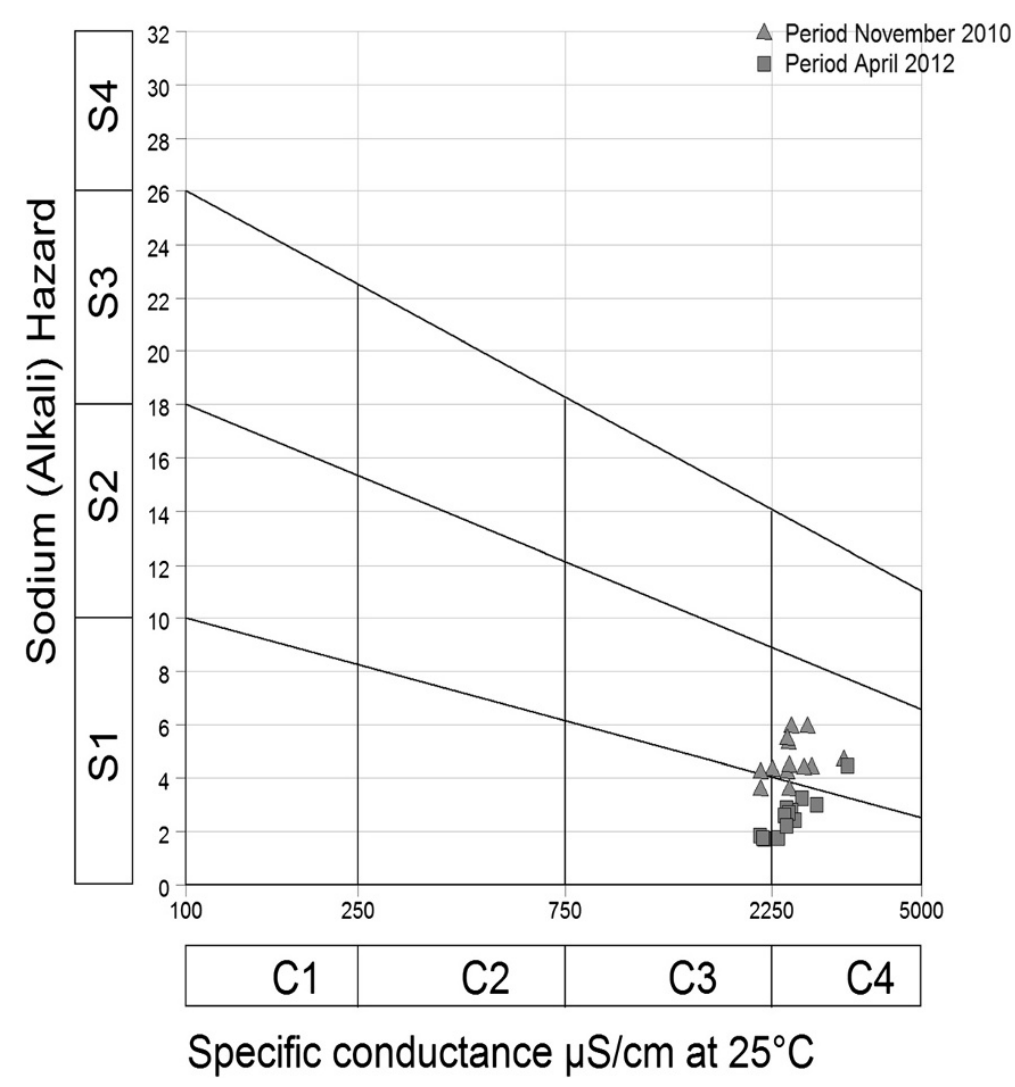

Figure 9 Salinity hazard of the $\mathrm{Cl}$ groundwaters of the study area (November 2010 and April 2012).

\section{Water quality for irrigation}

The suitability of groundwater for irrigation is dependent on the mineral constituents of water on the both the plant and soil (Maoui et al. 2010). In order to determine the suitability of groundwater for irrigation use, the Wilcox classification diagram (1955) in Figure 9 has been used. This graph is based on electrical conductivity (EC) and on sodium adsorption ratio (SAR). The SAR is of particular importance because a high Na content in irrigation water may increase soil hardness and reduce its permeability (Tijani 1994). High SAR can disperse soil aggregates, which in turn reduces the number of large pores in soil (Grattan 2002). Plotting of SAR on the Wilcox diagram (Figure 9) illustrates that most of the groundwater samples fall in the two fields (C3S1 and C4S1), indicating a very high salinity and low alkalinity hazard. This can be suitable for plants having good salt tolerance.

\section{Conclusions}

Groundwater in the Albian aquifer of Oued Righ shows a change in its chemical properties between the two sampling periods, resulting from water-rock interactions and mixing processes. The waters are generally of sodium and magnesium sulfated and sodium chlorinated types. The saturation indices of the study area show that evaporite minerals are undersaturated and carbonate minerals are oversaturated or nearly in equilibrium. The geothermal waters from the Oued Righ are immature waters, as indicated by the ternary diagram Na-k$\mathrm{Mg}^{1 / 2}$. Wilcox classification shows that most groundwater samples fall in to two fields (C3S1 and C4S1), indicating a very high salinity and low alkalinity hazard. 
Competing interests

The authors declare that they have no competing interests.

\section{Authors' contributions}

This research is a part of the phd thesis. NK supervisor of the phd thesis. WC carried out the sample analysis and drafted the manuscript. Both authors read and approved the final manuscript.

Received: 30 July 2013 Accepted: 29 January 2014

Published online: 12 April 2014

\section{References}

Bishop WF (1975) Geology of Tunisia and adjacent parts of Algeria and Libya. Bull Am Assoc Petrol Geol 59:413-450 Busson G (1967) Carte géologique du bassin Mésozoique du Sahara Algéro-Tunisien et de ses abords, planche 2

Castany G (1982) Bassin sédimentaire du Sahara septentrional (Algérie-Tunisie). Aquifères du continental intercalaire et du complexe terminal. Bull BRGM2 III(2):127-147

Cornet I (1964) Introduction à l'hydrogéologie Saharienne. Rev Géogr Phys et Géol Dyn VI(1):5-72

Deutsch WJ (1997) Groundwater Geochemistry: Fundamentals and application to contamination. Lewis publisher, USA Edmunds WM, Guendouz A, Mamou A, Moulla A, Shand P, Zouari K (2003) Groundwater evolution in the continental intercalaire aquifer of Southern Algeria and Tunisia: trace element and isotopic indicators. Appl Geochem 18:805-822

El-Fiky AA (2008) Hydrogeochemistry and geothermometry of thermal groundwater from the Gulf of Suez Region, Egypt.JKAU. Earth Sci 20(2):71-96

Giggenbach WF, Gonfiantini R, Jangi BL, Truesdell AH (1983) Isotopic and chemical composition of Parbati valley geothermal discharges, NW-Himalaya, India. Geothermics 12:199-222

Grattan SR (2002) Irrigation water salinity and crop production. Publication 8066, FWQP reference sheet 9.10. Division of Agriculture and Natural Resources. University of California, USA

Maoui A, Kherici N, Derradji F (2010) Hydrochemistry of an Albian sandstone aquifer in a semi arid region, Ain Oussera, Algeria. Environ Earth Sci 60:689-701. doi:10.1007/s12665-009-0207-1

Parkhurst DL, Appelo CAU (1999) User's guide to PHREEQC (version 2): a computer program for speciation, batch-reaction, one-dimensional transport, and inverse geochemical Calculations. USGS water-resources investigations report 99-4259

Pulmmer LN, Janes BF, Truesdell AH (1976) WATEQ_a Fortran IV version of WATEQ, a computer program for calculating chemical equilibrium of natural waters. US Geol Surv Water Res 76:13-61

Tarcan G, Gemici Ü (2003) Water geochemistry of the Seferihisar geothermal area, Izmir, Turkey. J Volcanol Geotherm Res 126:225-242

Tijani J (1994) Hydrochemical assessment of groundwater in Moro area, Kwara State, Nigeria. Environ Geol 24:194-202 UNESCO (1972) Etude des ressources en eau de Sahara septentrional. UNESCO, Paris

doi:10.1186/s40517-014-0003-3

Cite this article as: Chaib and Kherici: Hydrochemistry and geothermometry of an Albian aquifer from Oued Righ region in northeastern Algerian Sahara. Geothermal Energy 2014 2:3.

\section{Submit your manuscript to a SpringerOpen ${ }^{\circ}$ journal and benefit from:}

- Convenient online submission

- Rigorous peer review

- Immediate publication on acceptance

- Open access: articles freely available online

- High visibility within the field

- Retaining the copyright to your article

Submit your next manuscript at $\boldsymbol{\sim}$ springeropen.com 